F. med. Genet. (1965). 2, I31.

\title{
Chromosome Mosaicism in an Indian Child with Down's Syndrome
}

\author{
AMALA CHAUDHURI and K. C. CHAUDHURI \\ From The Chaudhuri Centre for Medical Genetics, Calcutta-14, India
}

Since the first report by Lejeune, Gautier, and Turpin in 1959 of the findings of trisomy 21 and a chromosome number of 47 in Down's syndrome (mongolism), several different chromosomal patterns have been described in patients with this disorder. One of these is chromosome mosaicism. In such cases, the patient may lack some of the features characteristic of the syndrome-and indeed some subjects with mosaicism are hardly distinguishable phenotypically from normal people (Fraccaro, Kaijser, and Lindsten, 1960; Hamerton, Briggs, Giannelli, and Carter, 196I; Blank Gemmell, Casey, and Lord, I962; Smith, Therman, Patau, and Inhorn, I962; Tonomura, Honda, and Kurita, 1962; Weinstein and Warkany, 1963).

Several cases of mosaicism in Down's syndrome are now on record and 24 are listed in Table I: 16 possess two types of cells containing 46 and 47 chromosomes respectively, i.e. are mosaics of normal and $2 \mathrm{I}$ trisomic cells (Aula, Hjelt, and Kauhtio, $196 \mathrm{I}$; Clarke, Edwards, and Smallpeice, 196I ; Hayashi, Hsu, and Chao, 1962; Lindsten, Alvin, Gustavson, and Fraccarro, 1962; Nichols, Coriell, Fabrizio, Bishop, and Boggs, 1962; Richards and Stewart, 1962; Giraud, Bernard, Stahl, Giraud, Hartung, and Lebeuf, 1963; Hayashi, 1963; Verresen, Van Den Berghe, and Van Den Berghe, 1963; Zellweger and Abbo, 1963; Gustavson, 1964; Stearns, Droulard, and Sahhar, 1960; Warkany, Weinstein, Soukup, Rubinstein and Curless, 1964; Zellweger and Abbo, I964); 2 have also two cell types but carry a possible isochromosome for the long arm of No. 2I (iso-1-2I) (Hamerton et al., 196I ; Blank, Lord, Casey, and Laurance, I963); 3 show triple cell lines with 46,47 , and 48 chromosomes, 2 of them with a probable isochromosome (Fitzgerald and Lycette, 196r; Gustavson and Ek, 196I; Gustavson, 1964; Mauer and Noe, 1964). One, reported by Valencia, de Lozzio, and de Coriat (1963), has several cell lines with

Received August 5, 1964 .
$46,47,48,49,50$, and 51 chromosomes in varying proportions; one is a trisomic 21 /pentasomic 21 mosaic (Piazzi and Rondinini, I96I); and one is a mosaic of normal cells and of cells carrying a 13-15/21 translocation (Franceschini, Volante, Ceppellini, De Carli, Nuzzo, and Torricelli, 1963). This paper reports another case of mosaicism in a patient with Down's syndrome, whose leucocytes on culture revealed two different complements, a normal one with 46 chromosomes and an abnormal one with 47 chromosomes, the extra chromosome belonging to the $G$ group. As expected, the chromosome number in the normal Indian has previously been reported to be 46 (Chaudhuri and Chaudhuri, I963a, b).

\section{Methods}

Chromosomal investigation was done by a modification of the technique of Moorhead, Nowell, Mellman, Battips, and Hungerford (1960) (Chaudhuri, 1963).

Smears from the oral mucosa were stained with $2 \%$ aceto-orcein and examined for the presence of Barr bodies. The percentage of Barr bodies in normal males found in this laboratory varies from $0-2 \%$.

\section{Case Report}

A 4-year-old Hindu boy from a vegetarian Marwari family in Indore came to the Centre because of mental backwardness. He was born normally at term to a healthy 22-year-old mother and 24-year-old father, who were not related to each other. He was the last in a sibship of three and the previous sibs were alive and well.

The infant did not cry at birth and the skull was soft both anteriorly and posteriorly. He was unable to suck at the breast and was fed expressed breast milk for 20 days. All the developmental milestones were delayed. He sat up at 12 months, started walking at $2 \frac{1}{2}$ years, cut his first tooth at 12 months, and did not learn to speak.

The facial appearance had some features of mongolism (Fig. I). The head circumference was 18.5 in. $(46.2 \mathrm{~cm}$.), there was slight epicanthus, and the nasal bridge was broad and flat. The lips were thick, the 
TABLE I

SOME DATA FROM REPORTED CASES OF MOSAICISM IN DOWN'S SYNDROME

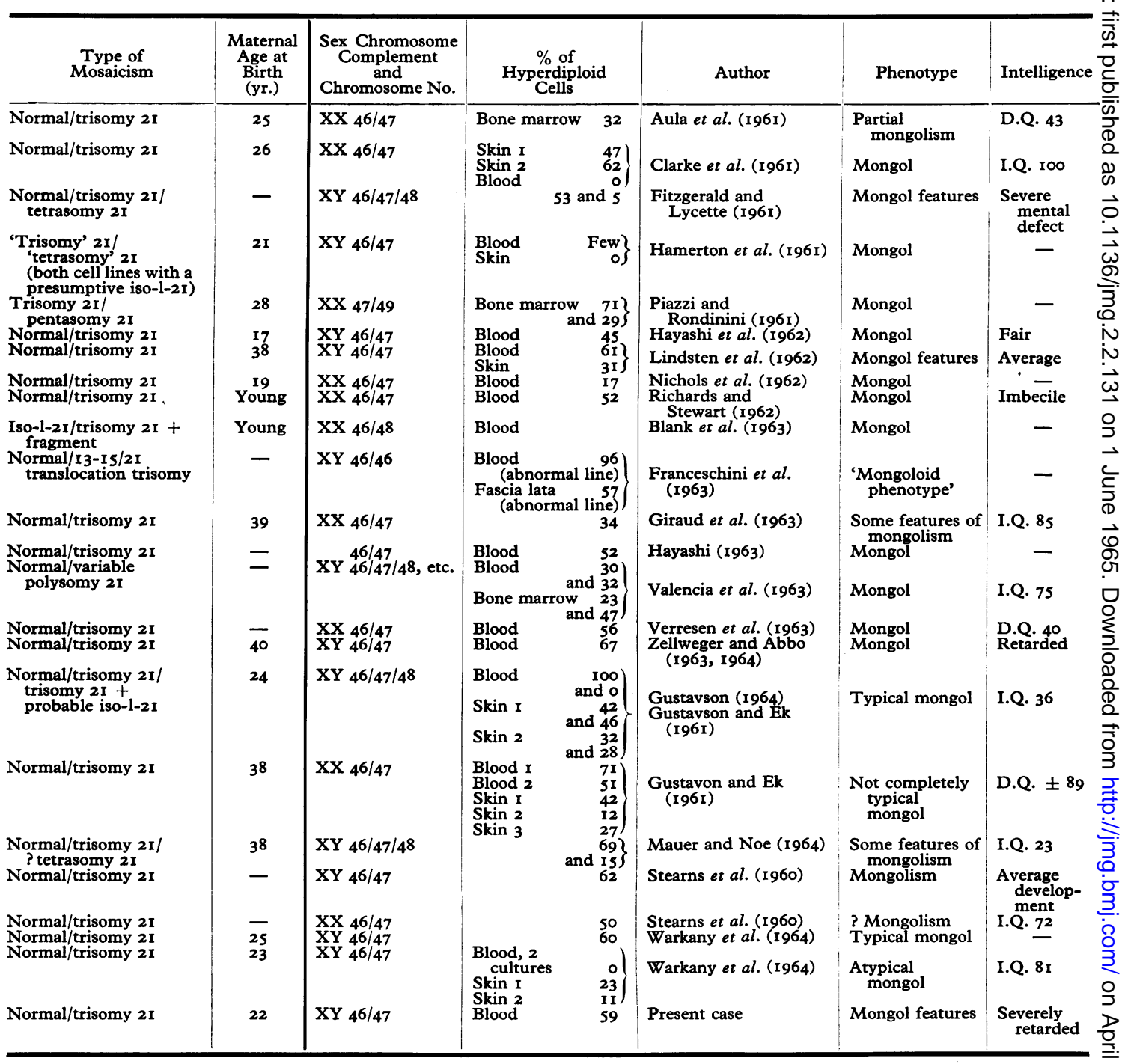

mouth was kept open, and the tongue protruded. He had a high-arched narrow palate and small irregular, malaligned teeth, some of which were peg-shaped, with diastasis. The hands were short with square palms and short broad fingers, but there were no single transverse palmar lines. Detailed analysis of the dermatoglyphic changes was not done and only the following data are available. The axial triradius was near the centre of the palm, there was absence of pattern in the thenar area, and the digital loop was present between digits III and IV. The fifth fingers were short and bent. The second toe on each foot was curved medially at the distal interphalangeal joint, with the toe-nails in an abnormal position. There was a wide space between the $N$ first and second toes. He was flat-footed, walked with an unsteady gait, and dragged his feet.

The heart, gastro-intestinal system, and external genitalia were normal. There was only a mild degree of $\stackrel{\circ}{\mathrm{C}}$ hyperextensibility of the joints and of hypotonia.

The child's attempt at language resulted in an inar- ? ticulate vocalization, but he was able to understand a $T$ few simple commands and to execute some of them.

Routine haematological examination was normal. Radiographs of the pelvis showed reduced acetabular $\mathbb{\mathbb { D }}$ 


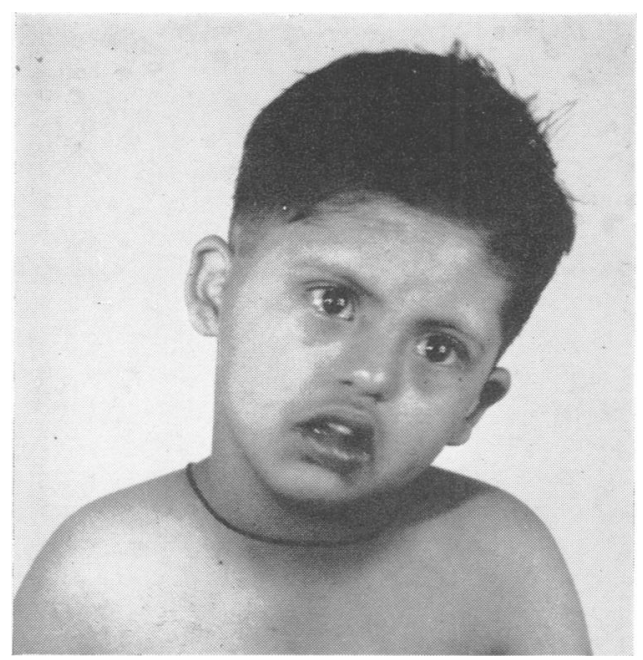

FIG. I. The 4-year-old patient with incomplete mongolism.

angles. There was hypoplasia of the middle phalanges of the fifth fingers.

\section{Chromosomal Studies}

Sixty-four cells in mitotic metaphase with well-spread chromosomes were examined: of these, $20(31 \%)$ contained 46 and $38(59 \%)$ had 47 chromosomes (Table II).

Karyotypes prepared from enlarged photomicrographs of seven metaphase plates containing 47 chromosomes showed six small acrocentric chromosomes. In
TABLE II

CHROMOSOME COUNTS IN THE PATIENT AND HIS MOTHER

\begin{tabular}{|c|c|c|c|c|c|c|}
\hline \multirow{2}{*}{$\begin{array}{l}\text { Type of } \\
\text { Culture }\end{array}$} & \multicolumn{5}{|c|}{ Number of Chromosomes } & \multirow{2}{*}{$\begin{array}{c}\text { Total } \\
\text { Cells } \\
\text { Counted }\end{array}$} \\
\hline & $<45$ & 45 & 46 & 47 & $>47$ & \\
\hline $\begin{array}{l}\text { Blood (patient) } \\
\text { Blood (mother) }\end{array}$ & $\begin{array}{l}2 \\
2\end{array}$ & $\begin{array}{l}\mathbf{I} \\
2\end{array}$ & $\begin{array}{l}20 \\
37\end{array}$ & 38 & $\begin{array}{l}3 \\
2\end{array}$ & $\begin{array}{l}64 \\
43\end{array}$ \\
\hline
\end{tabular}

keeping with the patient's phenotype the extra chromosome was probably a No. 2I (Fig. 2). Karyotypes of the cells with 46 chromosomes were normal.

A single sex chromatin mass was seen in $3 \%$ of the resting nuclei, a value higher than that usually found in this laboratory.

Chromosomal analysis of the mother's leucocytes revealed 46 chromosomes in 37 out of 43 cells. Karyotypes of four metaphase plates were all normal. The cells with chromosome counts varying from 44 to 48 were accounted for by random loss.

\section{Discussion}

Autosomal mosaicism of the numerical types described in the cases of Down's syndrome now on record could originate from mitotic nondisjunction after the first cleavage division of a normal zygote, from anaphase lagging in a zygote originally trisomic, or from a trisomic zygote if non-disjunction took place after the first cleavage division.

The predominance of trisomic cells in this patient might favour the hypothesis of an originally

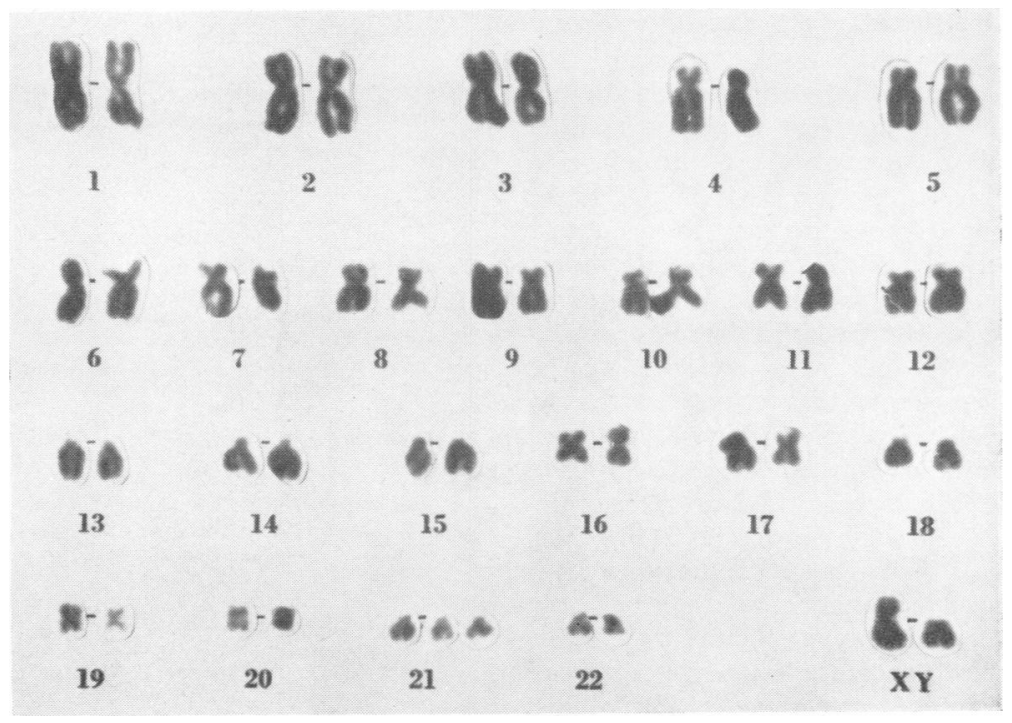

FIG. 2. Karyotype with six small acrocentrics. 
trisomic zygote. However, the proportions of the various cell types may differ in different tissues and in different areas from the same tissue, and furthermore change with time.

On the other hand, the mother of our patient was only 22 years old at the time of the patient's birth, and we can assume that non-disjunction in a normal zygote was the more likely cause of the mosaicism. Meiotic non-disjunction producing a trisomic zygote is usually associated with advancing maternal age. It is a remarkable fact that of the 17 mothers with mosaic offsprings whose ages are recorded, $12(71 \%)$ are below 28 years of age (Table I). As pointed out by Polani (1963), mosaicism may be of two types when considered in relation to maternal age, the one arising from normal zygotes and the other from trisomic 21 zygotes.

The presence of mosaicism in our patient may account for the incompleteness of the mongoloid state. While possessing several of the features of Down's syndrome, the patient lacked such stigmata as Brushfield's spots, slanting palpebral fissures, and furrowed tongue. Though some correlation appears to exist between the proportion of abnormal stem-lines and the physical features of the syndrome -the higher the proportion of abnormal cells, the greater the severity of the mongoloid condition - so far no definite relationship with respect to particular physical characters has yet been established.

Zellweger and Abbo (1963), from an analysis of the eight mosaics with Down's syndrome on record at that time, found a correlation between the level of intelligence and the proportions of the cell types-over $50 \%$ of abnormal cells being associated with severe mental retardation, while intelligence was fair to normal where normal cells predominated. This correlation may change with further reports on mosaics and with the accumulation of data on the proportions of the cell types between and within the tissues of the same patient. One of the recent cases reported (Valencia et al., 1963) had over $62 \%$ and $70 \%$ abnormal cells in blood and bone-marrow respectively, with six cell lines in the tissues, yet the I.Q. was as high as 75. The mongol of Lindsten et al. (1962), who was of average intelligence, had $61 \%$ trisomic cells in one of two tissues examined. A mother with the stigmata of Down's syndrome who had a child with classical mongolism, described by Blank et al. (1962), had only $14 \%$ and II $\%$ cells with 2 I-trisomy in two separate leucocyte cultures, and her I.Q. was only 60; whereas Richards and Stewart's (1962) mosaic was an imbecile with just over $50 \%$ trisomic cells. The intelligence quotient was not determined in our patient, but he was apparently severely mentally retarded with $59 \%$ trisomic cells.

It is apparent from the data available at present on mosaicism in Down's syndrome that it is not yet possible to establish a definite relation between the proportions of the various cell lines and either the type of zygote responsible for the mosaicism or the physical features and level of intellectual attainment. As more data become available on the proportions of the cell-lines in several tissues of the same patient with mosaicism, the differences, if any, will become more apparent, which might then allow proper correlation to be made between these proportions and phenotypic expression.

\section{Summary}

Mosaicism with two cell lines consisting of 옥 46 and 47 (with an extra $G$ ) chromosomes respectively in a 4-year-old Indian boy with Down's syndrome is described.

The question of the correlation between the proportions of the cell-types and the phenotype in mongols with mosaicism is briefly discussed.

The authors wish to thank Professor Paul E. Polani, of the Paediatric Research Unit, Guy's Hospital Medical School, London, for very kindly reading through the manuscript, and for his valuable suggestions and additions to the paper.

The authors also thank Dr. H. P. Klinger of the Department of Anatomy (Genetics), Albert Einstein College of Medicine, New York, for his many helpful suggestions during the establishment of their cytogenetics unit where the above investigation was carried out.

We are also grateful to Ciba (Basle) Ltd., Switzerland, for the supply of Colcemid used in the investigation.

\section{REFERENCES}

Aula, P., Hjelt, L., and Kauhtio, J. (196I). Chromosomal investigation in congenital malformations. Ann. Paediat. Fenn., 7, 206.

Blank, C. E., Gemmell, E., Casey, M. D., and Lord, M. (1962). Mosaicism in a mother with a mongol child. Brit. med. F., 2, 378 . , Lord, P. M., Casey, M. D., and Laurance, B. M. (1963). Chromosome mosaicism in a mongol born to a young mother. Cytogenetics, 2, 76.

Chaudhuri, A. (1963). Simplified method for obtaining leucocytes $N$ for culture from peripheral blood. Hum. Chromos. Nerwsl., No. I I, 요 I8. man. Indian F. Pediat., 30, 75.

- and - (1963b). The karyotype in normal Indians. Hum. Chromos. Newsl., No. I1, 2.

Clarke, C. M., Edwards, J. H., and Smallpeice, V. (1961). 2 ITrisomy/normal mosaicism in an intelligent child with some mongoloid characters. Lancet, $\mathrm{I}, 1028$.

Fitzgerald, F. H., and Lycette, R. R. (1961). Mosaicism in man involving the autosome associated with mongolism. ibid., 2,212 .

Fraccaro, M., Kaijser, K., and Lindsten, J. (I960). Chromosomal abnormalities in father and mongol child. ibid., 1,724 . 
Franceschini, P., Volante, G., Ceppellini, R., De Carli, L., Nuzzo, F., and Torricelli, C. (1963). Mosaico cromosomico traslocazione 21 su 13-15 normale in un individuo mongoloide. Atti Ass. genet. ital., 8, ror.

Giraud, P., Bernard, R., Stahl, A., Giraud, F., Hartung, N., and Lebeuf, M. (1963). Mosaïque chromosomique chez une mongolienne avec un Q.I. à 0,85 . Pédiatrie, 18, 753 .

Gustavson, K.-H. (1964). Down's Syndrome, a Clinical and Cytogenetical Investigation. Institute for Medical Genetics of the University of Uppsala. Almquist and Wiksell, Uppsala.

, and Ek, J. I. (I96I). Triple stem-line mosaicism in mongolism. Lancet, 2, 319.

Hamerton, J. L., Briggs, S. M., Giannelli, F., and Carter, C. O. (196I). Chromosome studies in detection of parents with high risk of second child with Down's syndrome. ibid., 2, 788.

Hayashi, T. (1963). Karyotypic analysis of 83 cases of Down's syndrome in Harris County, Texas. Tex. Rep. Biol. Med., $21,28$. -, Hsu, T. C., and Chao, D. (1962). A case of mosaicism in mongolism. Lancet, $1,218$.

Lejeune, J., Gautier, M., and Turpin, R. (1959). Étude des chromosomes somatiques de neuf enfants mongoliens. C.R. Acad. Sci. (Paris), 248, 1721.

Lindsten, J., Alvin, A., Gustavson, K. H., and Fraccarro, M. (1962). Chromosomal mosaicism in a girl with some features of mongolism. Cytogenetics, $\mathbf{1}, 20$.

Mauer, I., and Noe, O. (I964). Triple stem-line chromosomal mosaicism in Down's syndrome (mongolism). Lancet, $\mathbf{x}, 666$

Moorhead, P. S., Nowell, P. C., Mellman, W. J., Battips, D. M., and Hungerford, D. A. (1960). Chromosome preparations of leukocytes cultured from human peripheral blood. Exp. Cell Res., 20, 613.

Nichols, W. W., Coriell, L. L., Fabrizio, D. P. A., Bishop, H. C., and Boggs, T. R., Jr. (1962). Mongolism with mosaic chromosome pattern. F. Pediat., 60, 69 .
Piazzi, G., and Rondinini, B. (I96I). Double mosaic in mongolism. (In Italian.) Clin. Pediat. (Bologna), 43, 934.

Polani, P. E. (1963). Cytogenetics of Down's syndrome (mongolism). Pediat. Clin. N. Amer., 10, 423.

Richards, B. W., and Stewart, A. (1962). Mosaicism in a mongol. Lancet, I, 275.

Smith, D. W., Therman, E. M., Patau, K. A., and Inhorn, S. L. (1962). Mosaicism in mother of two mongoloids. Amer. F. Dis. Child., 104, 534.

Stearns, P. E., Droulard, K. E., and Sahhar, F. H. (1960). Studies bearing on fertility of male and female mongoloids. Amer. $\mathcal{f}$. ment. Defic., 65, 37.

Tonomura, A., Honda, T., and Kurita, T. (1962). Chromosome abnormalities in a child with Down's syndrome and in its father. Proc. Fap. Acad., 38, 526.

Valencia, J. I., de Lozzio, C. B., and de Coriat, L. F. (I963). Heterosomic mosaicism in a mongoloid child. Lancet, 2, 488.

Verresen, H., Van Den Berghe, H., and Van Den Berghe, G. (I963). Considérations sur l'expression clinique du mongolismemosaïcisme (46 normal, 47 trisomie 21, avec présentation d'un cas). Acta paediat. belg., 17, 137.

Warkany, J., Weinstein, E. D., Soukup, S. W., Rubinstein, J. H., and Curless, M. C. (1964). Chromosome analyses in a children's hospital. Pediatrics, 33, 290.

Weinstein, E. D., and Warkany, J. (1963). Maternal mosaicism and Down's syndrome (mongolism). F. Pediat., 63, 599.

Zellweger, H., and Abbo, G. (1963). Chromosomal mosaicism and mongolism. Lancet, $1,827$.

- and - (1964). Moderne Mongolismus-Probleme: Mongolismus, Paramongolismus und mongoloide Stigmatisierung in klinischer und zytogenetischer Betrachtung. Dtsch. med. Wschr., 89, 405 . 